\title{
Novel poly- $\beta$-cyclodextrin derivatives as advanced carriers for 5-fluorouracil for tumor: the impact of charge on antitumor efficiency
}

\author{
Hailang $\mathrm{Li}^{1}$, Shanshan $\mathrm{Zhu}{ }^{1}, \mathrm{Li} \mathrm{Xu}^{1}$, Yupei Chen ${ }^{2}, \mathrm{Xin}_{\mathrm{Li}^{3}}$, Wenlin $\mathrm{Wu}^{4}$ \\ ${ }^{1}$ Department of Pharmacy, Xiamen Medical College of Fujian Province, Xiamen, China; ${ }^{2}$ Engineering Research Center of Natural Cosmeceuticals \\ College of Fujian Province, Xiamen Medical College, Xiamen, China; ${ }^{3}$ Shanghai Serum-China Bio-Tech. Co., Ltd., Shanghai, China; ${ }^{4}$ College of \\ Oceanology and Food Science, Quanzhou Normal University, Quanzhou, China \\ Contributions: (I) Conception and design: H Li, W Wu; (II) Administrative support: H Li, S Zhu; (III) Provision of study materials or patients: L Xu; \\ (IV) Collection and assembly of data: H Li, S Zhu; (V) Data analysis and interpretation: H Li, X Li, W Wu; (VI) Manuscript writing: All authors; (VII) \\ Final approval of manuscript: All authors. \\ Correspondence to: Wenlin Wu. College of Oceanology and Food Science, Quanzhou Normal University, Quanzhou 362000, China. \\ Email: wenlinw@163.com.
}

Background: With the emergence of more and more cyclodextrin derivatives, cyclodextrin becomes an effective adjuvant for improving the prescription of drugs. Its application in pharmacy, especially in the sustained and controlled release, targeting, transdermal and mucosal drug delivery systems, is also being expanded and deepened. In this study, novel cyclodextrin derivatives were developed to investigate the impact of the charge on antitumor efficiency by introducing different groups (carboxymethyl or quaternary ammonium group) to poly- $\beta$-cyclodextrin ( $\beta$-CD).

Methods: These novel $\beta$-CD derivatives were prepared by the nucleophilic substitution reaction and characterized by IR and ${ }^{1} \mathrm{H}$ NMR. Fluorouracil (5-FU) was adopted as a model drug to form inclusion compounds. The content of 5-FU in inclusion compounds was evaluated using fluorine element analysis. Also, the cytotoxicity of poly- $\beta-C D$ derivatives was studied. Finally, the effect of negative and positive charges on the antitumor activity of poly- $\beta$-CD derivatives-5-FU inclusion compounds on HepG2 cancer cells was evaluated. Human liver cancer HepG2 cells (CYP3A4G/7R clone 87, RRID: CVCL_1×10) were purchased from Cell Bank, Shanghai Institutes for Biological Sciences (China).

Results: The results of IR and $1 \mathrm{H}$ NMR indicated consistently that both carboxymethyl poly- $\beta-\mathrm{CD}$ (poly-CM- $\beta-C D$ ) and glycidyl trimethyl ammonium chloride (GTMAC) poly- $\beta-C D$ (poly-GTAC- $\beta$-CD) were successfully prepared. Fluorouracil was successfully loaded into poly- $\beta$-CD derivatives. The results of fluorine analysis indicated that the content of $5-\mathrm{FU}$ in $1 \mathrm{~g}$ poly- $\beta-\mathrm{CD}$, poly-GTAC- $\beta-\mathrm{CD}$ and poly-CM- $\beta$ CD was $1,214,921$ and $1,187 \mu \mathrm{g}$, respectively. No cytotoxicity of poly- $\beta$-CD derivatives on HepG2 cells was observed. The killing effect of poly- $\beta-C D-5-F U$ on HepG2 cells was similar to that of poly-GTAC- $\beta-C D-5-$ FU. Poly-CM- $\beta$-CD-5-FU had the worst killing effect on HepG2 cells.

Conclusions: Charge had impact on antitumor efficiency. These novel poly- $\beta$-CD derivatives have potential applications in tumor sustained-release targeted therapy.

Keywords: Poly- $\beta$-cyclodextrin ( $\beta$-CD); different groups; advanced carriers; 5 -fluorouracil (5-FU); tumor

Submitted Feb 20, 2020. Accepted for publication Jul 03, 2020.

doi: $10.21037 /$ tcr-20-1118

View this article at: http://dx.doi.org/10.21037/tcr-20-1118 


\section{Introduction}

Cancer is regarded as one of the main problems threatening the health of humanity. The percentage of the reported patient numbers was expected to be increased by $75 \%$ by the next two decades (1). Liver cancer is the most obstinate malignant tumors. This enlightened researchers on developing low cost, efficient, and safe therapies for cancer or taking advantage of new technologies to improve the potential of the currently used drugs (2). 5-fluorouracil (5-FU), commonly used anticancer drug, has an efficient effect on active cancers (3). However, 5-FU drugs can not only kill the cancer cells but also affect the normal cells, causing several negative impacts in the course of treatment (4). Furthermore, an overdose of 5-FU can result in impair the hematological, neural, cardiac, gastrointestinal tract as well as the dermatological reactions (1). Thus, it was a requisite for developing a novel carrier to control the drug release in the specific lesion, and minimize its side effect as far as possible (5). To achieve this goal, numerous materials, such as bentonite, biodegradable polymers, chitosan, alginate, and cellulose, etc., were inspected and evaluated (6). Polymeric nano-carriers which were biocompatible, nontoxic, and stable in the biological systems were promising drug carriers with high encapsulation and controlled release properties (7).

$\beta$-cyclodextrin ( $\beta-C D)$, a known natural polymer with size in nanoscale, is composed of seven $\alpha-\mathrm{D}$ units of glucose which linked to echo with $\alpha-1,4$-glucose bonds (8). The central cavities of $\beta-C D$ are lipophilic and its outer surface is hydrophilic. These properties make $\beta$-CD interact with lipophilic guest molecules, forming a host-guest inclusion compound by self-assembly (9). It was reported that $\beta$-CD can be used as excipient materials, improving the stability and oral bioavailability of the drug (10). The notable feature of cyclodextrins is their ability to form solid inclusion hostguest complexes with a wide range of solid, liquid, and gaseous compounds by a molecular complexation (11). The driving force for the formation of an inclusion compound was mainly from the release of water molecules in the cavity of cyclodextrin. It was difficult to fully form a hydrogen bond between water molecules in the hydrophobic cavity of cyclodextrin. Nevertheless, the potential of water molecules to form hydrogen bonds was not fully released. Therefore, water molecules in the hydrophobic cavity of cyclodextrin had considerable enthalpy. When these highenergy water molecules were replaced by suitable guest molecules with smaller polarity and released from the hydrophobic cavity of cyclodextrin, the energy of these systems would be reduced, facilitating the formation of inclusion compounds. During the formation of inclusion compounds, the removal of high energy water molecules from the hydrophobic cavity of cyclodextrins was the main driving force. Additionally, the driving force also included van der Waals force (12), hydrogen bond interaction (13), hydrophobic interaction (14), non-classical hydrophobic interaction, the reduction of ring tension in the formation of inclusion compounds and the decrease of surface tension of solvent (15). It was also documented that integrating or grafting the hydrophilic monomer with $\beta$-CD can increase its complexation efficiency with the drugs and decrease the cost of $\beta$-CD polymer (16). Additionally, it was reported that polymerizing $\beta-\mathrm{CD}$ with other polymers can increase its solubility and bioavailability (17). This advantage can result in the pro-apoptosis of melanoma cells by using the complexation of harman, a natural $\beta$-carboline alkaloid, with $\beta$-CD (18). On the other hand, the curcumin, a natural polyphenol, with $\beta-C D$ and $\gamma-C D$ showed superior in antioxidant, antibacterial, and anticancer activities (19). However, the biggest problem of cyclodextrin drug carrier is its low drug loading efficiency (20).

It was demonstrated that the gap of tumor vascular endothelial cells is $380-780 \mathrm{~nm}(21)$. This abnormal permeability of tumor vessels makes the permeability of macromolecular and nanoparticles increase and lymphatic clearance reduce. However, there is no difference in the distribution of small molecule drugs between tumor tissues and normal tissues. The difference of permeability between tumor tissues and normal tissues makes macromolecule and nanoparticles aggregate in tumor tissue, which is called enhanced permeability and retention (EPR). EPR is the basis of tumor-targeting for nanoparticles (22). The cell membrane is composed of the phospholipid bilayer and the surfaces of the cell are negatively charged. Therefore, it was expected that the introduction of carboxymethyl or quaternary ammonium group to $\beta-C D$ resulted in a novel $\beta$-CD derivatives, which can increase the solubility of $5-\mathrm{FU}$ by facilitating its loading and enhance the potential of $5-\mathrm{FU}$ for inhibiting the tumor cells by boosting the combination of $\beta$-CD inclusion compounds to tumor cell.

In this study, the novel $\beta$-CD derivatives by grafting different groups (carboxymethyl or quaternary ammonium group) to poly- $\beta-C D$ were developed as delivery systems for the 5-FU drug and could be applied in the liver cancer therapy. The novel poly- $\beta-C D$ was characterized by IR and ${ }^{1} \mathrm{H}$ NMR. 5-FU was adopted as a model drug to form an 
inclusion compound. The content of $5-\mathrm{FU}$ in poly- $\beta-\mathrm{CD}$ derivatives was evaluated using fluorine element analysis. The self-assembly and its mechanism were explored in detail. Also, the cytotoxicity of poly- $\beta-C D$ derivatives was analyzed. Finally, the potential of poly- $\beta-\mathrm{CD}$ derivatives-5-FU inclusion compounds for HepG2 cancer cells was evaluated.

\section{Methods}

\section{Materials}

Poly- $\beta$-cyclodextrin (poly- $\beta$-CD) (Mw, 5,000-10,000 Da) was provided by Shandong Binzhou Zhiyuan Biotechnology Co., Ltd. (Shandong, China). 5-FU, glycidol trimethyl ammonium chloride, dimethyl sulfoxide (DMSO), bromoacetic acid, cell culture media and supplements, fetal bovine serum (FBS), and alamar blues were purchased from Sigma-Aldrich (Shanghai, China). Dialysis tubing with an Mw cut-off of 1,500-2,000 Da was purchased from Spectrum Laboratories (Miami, FL, USA). Unless stated otherwise, all reagents and solvents were commercially available analytic grade reagents and were used without further purification.

\section{Preparation of glycidyl trimethyl ammonium chloride

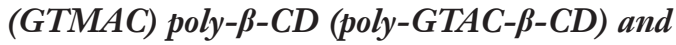 carboxymethyl poly- $\beta-C D$ (poly-CM-CD)}

To prepare poly-GTAC- $\beta-C D, 0.01$ mole GTMAC and 0.01 mole poly- $\beta-C D$ were mixed in a $50 \mathrm{~mL}$ roundbottom flask. On the hand, 0.01 mole bromoacetic acid and 0.01 mole poly- $\beta-C D$ were mixed for poly-CM- $\beta$ CD. Ten milliliters DMSO was added into the mixture and stirred. To remove the DMS and residual small molecular compound, the dialysis membrane of Spectra/Por 1,500 2,000 Da was utilized. The resultant product was collected by lyophilization.

\section{Fourier transform IR spectra}

Fourier transform IR spectra of poly-GTAC- $\beta-C D$ and poly-CM- $\beta$-CD were measured over $4,000-400 \mathrm{~cm}^{-1}$ on a Perkin-Elmer Spectrum 2000 instrument (Perkin Elmer, Boston, MA, USA) with $\mathrm{KBr}$ sample pellets.

\section{${ }^{1} \mathrm{H}$ NMR spectra}

Both poly-GTAC- $\beta-C D$ and poly-CM- $\beta-C D$ structures were further confirmed by ${ }^{1} \mathrm{H}$ NMR. The ${ }^{1} \mathrm{H}$ NMR spectra were recorded in $\mathrm{D}_{2} \mathrm{O}$ on a Bruker AC 200P, 200 $\mathrm{MHz}$ spectrometer (Bruker Corporation, Rheinstetten, Germany), using tetramethylsilane as the internal standard.

\section{The preparation of inclusion complexes}

Four-gram poly-GTAC- $\beta-\mathrm{CD}$ and poly-CM- $\beta$-CD were respectively added into $10 \mathrm{~mL}$ DMSO and $1 \mathrm{~g} 5$-FU in $50 \mathrm{~mL}$ round-bottom flask. The mixture was stirred with reflux at $80{ }^{\circ} \mathrm{C}$ for $72 \mathrm{~h}$. The DMSO and residual small molecular compound were removed by dialysis for 72 hours using the dialysis membrane of Spectra/Por 1,500-2,000 Da. The resultant product was collected by lyophilization.

\section{Determination of the 5-FU loading content in poly-CM- $\beta$ - $C D$ and poly-GTAC- $\beta-C D$}

The content of $5-\mathrm{FU}$ in poly-GTAC- $\beta-\mathrm{CD}$ or poly-CM- $\beta$ $\mathrm{CD}$ was evaluated using fluorine element analysis. Briefly, a $100 \mathrm{mg}$ sample was wrapped in ashless paper and placed in a $500 \mathrm{~mL}$ oxygen flask containing $5 \mathrm{~mL}$ absorbing liquid for combustion. Fluoride in the resultant absorbing liquid was separated using IonPac AS14-AG14 (Dionex, Sunnyvale, CA, USA) as a separating column and rinsing with a solution containing $0.001 \mathrm{M} \mathrm{NaHCO}_{3}$ and $0.0035 \mathrm{M}$ $\mathrm{Na}_{2} \mathrm{CO}_{3}$. The electric conductivity was detected.

\section{Cell culture}

Human liver cancer HepG2 cells (CYP3A4G/7R clone 87, RRID: CVCL_1 $1 \times 10)$ were purchased from Cell Bank, Shanghai Institutes for Biological Sciences (China). HepG2 was cultured in DMEM medium supplemented with $10 \%$ heat-inactivated FBS, $1.0 \mathrm{mM}$ sodium pyruvate, $0.1 \mathrm{mM}$ unessential amino acid and $1.5 \mathrm{~g} / \mathrm{L} \mathrm{NaHCO}_{3}$. All cells were cultured in a fully humidified atmosphere containing $5 \%$ $\mathrm{CO}_{2}$ at $37^{\circ} \mathrm{C}$.

\section{In vitro cytotoxicity assay of poly-CM- $\beta-C D$ and poly- GTAC- $\beta-C D$}

HepG2 cell lines were seeded in a 24-well plate at a density of $5.0 \times 10^{4} \mathrm{cell} / \mathrm{mL}$ and incubated overnight at $37^{\circ} \mathrm{C}$ and $5 \%$ $\mathrm{CO}_{2}$ to attain subconfluence before treating with poly-CM$\beta-C D /$ poly-GTAC- $\beta-C D$ at various concentrations. After two days post-incubation, cells in each well were exposed to $0.4 \mathrm{~mL} 2 \%$ crystal violet in $20 \%$ methanol for $30 \mathrm{~min}$ 
at room temperature and rinsed with distilled water in preparation for image analysis.

\section{Evaluation of the potential of poly-CM- $\beta-C D-5-F U /$ poly-GTAC- $\beta-C D-5-F U$ inclusion compounds for HepG2 cancer cells}

The potential of poly-CM- $\beta-\mathrm{CD}-5-\mathrm{FU} /$ poly-GTAC$\beta-\mathrm{CD}-5-\mathrm{FU}$ inclusion compounds was evaluated using HepG2 cells and the 3-(4,5-dimethylthiazol-2-yl)-2,5diphenyltetrazolium bromide (MTT) assay. HepG2 cells were seeded in 96-well plates at a density of $1 \times 10^{4}$ cells/ well in $100 \mu \mathrm{L}$ cell culture medium and incubated overnight to obtain $75-80 \%$ confluency. The culture medium was then replaced with fresh, serum free medium, and a serial sample of poly-CM- $\beta$-CD-5-FU/poly-GTAC- $\beta-C D-5-$ $\mathrm{FU}$ inclusion compound was added to the cells. Cells were incubated with poly-CM- $\beta-C D-5-F U /$ poly-GTAC- $\beta$ $\mathrm{CD}-5-\mathrm{FU}$ inclusion compound at a $5-\mathrm{FU}$ concentration of $5 \mu \mathrm{g} / \mathrm{mL}$ for the originally seeded cells at $37^{\circ} \mathrm{C}$. Then, cells were incubated for $24 \mathrm{~h}$. A total of $10 \mu \mathrm{L}$ MTT solution $(25 \mu \mathrm{g} / \mathrm{mL}$ ) was added to the $100 \mu \mathrm{L}$ of culture medium in each well before incubation at $37^{\circ} \mathrm{C}$ for $4 \mathrm{~h}$. The MTTcontaining medium was replaced with $100 \mu \mathrm{L}$ solubilization solution DMSO. Finally, the absorbance was measured at $595 \mathrm{~nm}$ using an ELISA plate reader (Thermo Fisher, Waltham, MA, USA) with a reference filter of $650 \mathrm{~nm}$. The viability of non-treated control cells was arbitrarily defined as $100 \%$. The experiment was repeated four times for each sample treatment. Cell viability (\%) was calculated according to the following Eq. [1]:

$$
\frac{O D_{595}(\text { sample })-O D_{650}(\text { sample })}{O D_{595}(\text { control })-O D_{650}(\text { control })} \times 100
$$

where $\mathrm{OD}_{595}$ (sample) and $\mathrm{OD}_{650}($ sample) represent measurements from the wells treated with poly-CM- $\beta-C D-$ 5 -FU/poly-GTAC- $\beta$-CD-5-FU inclusion compounds and $\mathrm{OD}_{595}$ (control) and $\mathrm{OD}_{650}$ (control) represent measurements from the wells treated with only DMEM containing $10 \%$ fetal calf serum.

\section{Statistical analysis}

All experiments were repeated four times and measurements were collected in quadruplicate. Data are expressed as the mean \pm standard deviation based on four measurements. Statistical analysis was performed using Student's $t$-test. $\mathrm{P}<0.005$ was considered to indicate a statistically significant difference.

\section{Results}

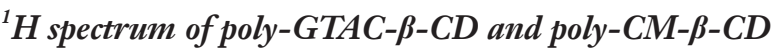

The successful synthesis of poly-GTAC- $\beta$-CD and polyCM- $\beta$-CD was confirmed by ${ }^{1} \mathrm{H}$ NMR spectra. Typical ${ }^{1} \mathrm{H}$ spectra of poly-GTAC- $\beta-C D$ and poly-CM- $\beta-C D$ were showed in Figures 1 and 2, respectively. Chemical shifts and corresponding protons were analyzed in Table 1 .

\section{IR spectroscopy of poly-GTAC- $\beta-C D$ and poly-CM- $\beta-C D$}

To further confirm the formation of poly-GTAC- $\beta-C D$ and poly-CM- $\beta-C D$, IR spectroscopy of poly-GTAC- $\beta-C D$ and poly-CM- $\beta-C D$ was performed. The FT-IR spectrum of poly- $\beta-C D$, poly-GTAC- $\beta-C D$, and poly-CM- $\beta-C D$, with or without reaction, was illustrated in Figure 3. According to the Table 2, it was indicated that the FT-IR spectrum of poly-GTAC- $\beta-C D$ and poly-CM- $\beta-C D$ can reappear the characteristic absorption peaks of 2,3-epoxypropyltrimeth ylammonium chloride and $\mathrm{Br}-\mathrm{CH}_{2} \mathrm{COOH}$. These results were consistent with the expected chemical structures polyGTAC- $\beta-C D$ and poly-CM- $\beta-C D$.

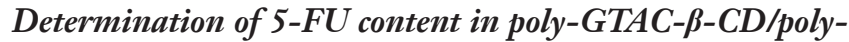 $C M-\beta-C D$}

To determine the percentage of 5 -FU loaded in polyGTAC- $\beta-C D /$ poy-CM- $\beta-C D$, the fluorine element analysis was conducted following freeze-drying of the conjugate. The result indicated that the content of $5-\mathrm{FU}$ in $1 \mathrm{~g}$ poly$\beta-\mathrm{CD}$, poly-GTAC- $\beta-\mathrm{CD}$, and poly-CM- $\beta-\mathrm{CD}$ was 1,214 , 921 and $1,187 \mu \mathrm{g}$, respectively.

\section{In vitro cytotoxicity of poly-CM- $\beta-C D$ and poly-GTAC- $\beta-$ $C D$}

For the concerns of efficient drug delivery, biocompatibility and cytotoxicity of poly-GTAC- $\beta-C D$ and poly-CM- $\beta-C D$, HepG2 cell lines were selected for the in vitro cytotoxicity analysis and incubated with poly-GTAC- $\beta$-CD or polyCM- $\beta$-CD for $72 \mathrm{~h}$. Crystal violet stain was used to assay cell viabilities in the presence of poly-GTAC- $\beta-C D$ or poly-CM- $\beta-C D$, and phosphate buffered saline was utilized as the control. As illustrated in Figure 4, Figure 4A1,A2,B1 and $B 2$, for poly-CM- $\beta-C D$ and poly-GTAC- $\beta-C D$, 


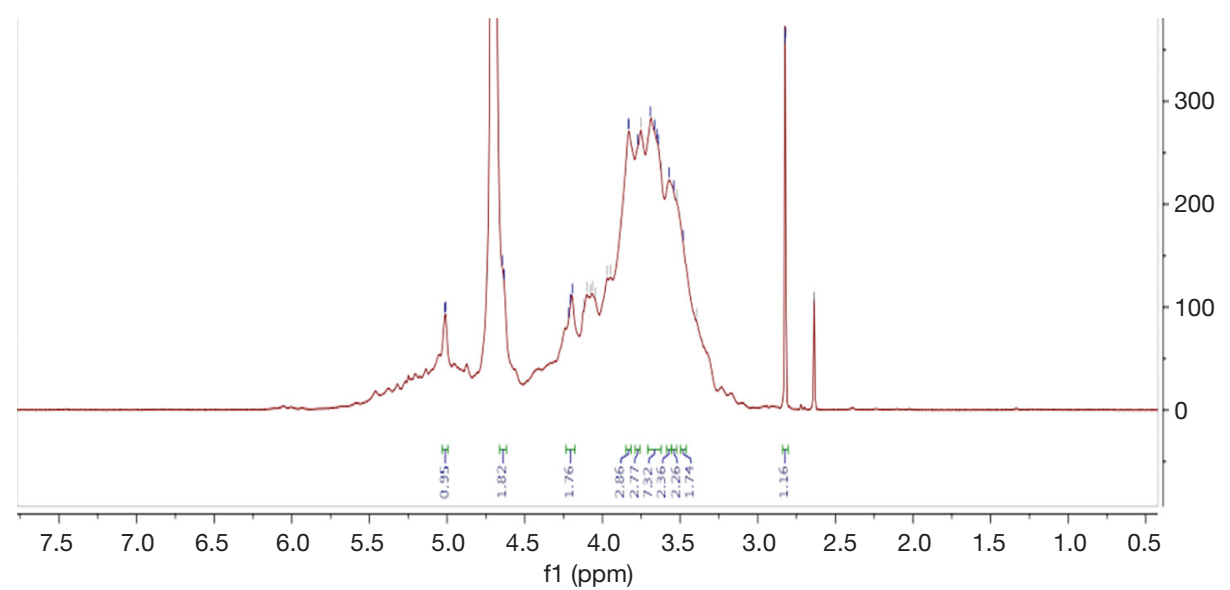

Figure 1 The ${ }^{1} \mathrm{H}-\mathrm{NMR}$ spectra of poly-GTAC- $\beta-\mathrm{CD}$.

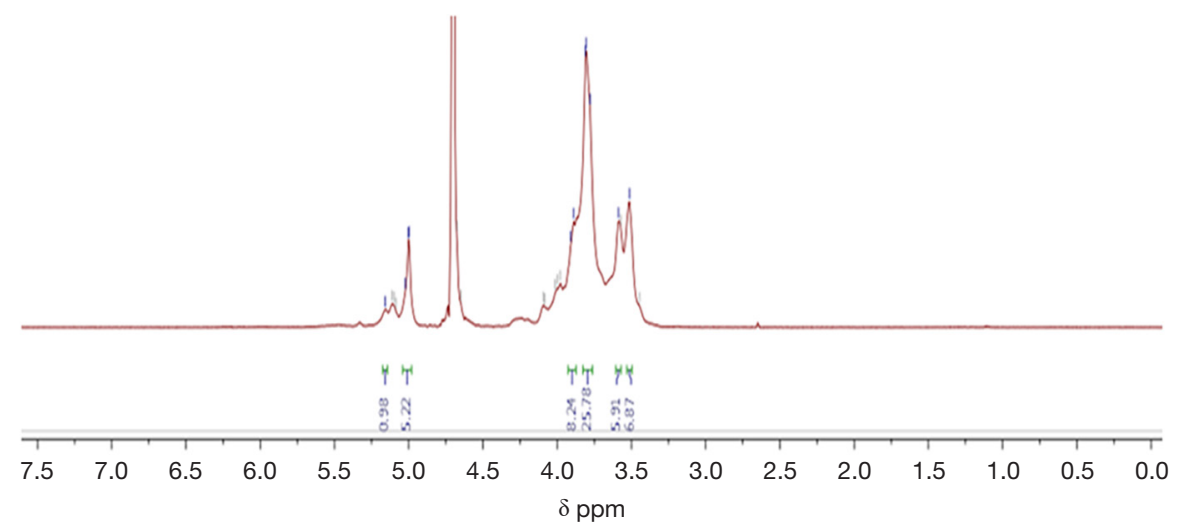

Figure 2 The ${ }^{1} \mathrm{H}-\mathrm{NMR}$ spectra of poly-CM- $\beta-\mathrm{CD}$.

Table 1 The chemical shifts of poly-GTAC- $\beta$-CD as well as poly-CM- $\beta-\mathrm{CD}$ and its corresponding protons

\begin{tabular}{lc}
\hline Chemical shift $\delta_{\mathrm{H}} / \mathrm{ppm}$ & Annotation \\
\hline $5.76-5.60$ & $\mathrm{OH}-2, \mathrm{OH}-3$ of poly- $\beta-\mathrm{CD}$ \\
$4.87-4.76$ & $\mathrm{OH}-1$ of poly- $\beta-\mathrm{CD}$ \\
$4.52-4.36$ & $\mathrm{OH}-6$ of poly- $\beta-\mathrm{CD}$ \\
$4.139-4.1408$ & $-\mathrm{O}-\mathrm{CH}_{2}-\mathrm{COOH}$ \\
$9.0-12.0$ & $-\mathrm{COOH}$ \\
$3.3001-3.3008$ & $-\mathrm{N}^{+}\left(\mathrm{CH}_{3}\right)$ \\
\hline
\end{tabular}

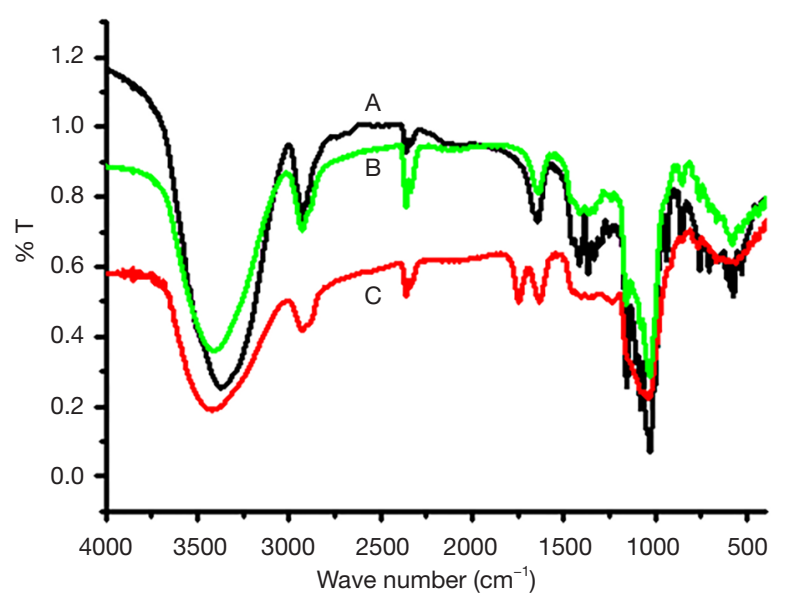

Figure 3 The IR spectra of (A) poly- $\beta$-cyclodextrin, (B) polyGTAC- $\beta-C D$ and $(C)$ poly-CM- $\beta-C D$. 
Table 2 The wave number of poly-GTAC- $\beta-C D$ as well as poly-CM- $\beta-C D$ and its corresponding IR vibration

\begin{tabular}{ll}
\hline Wave number/cm & Annotation \\
\hline $1,770-1,750$ & the $\mathrm{C}=\mathrm{O}$ stretching vibration of $-\mathrm{COOH}$ \\
$1,190-1,001$ & $\mathrm{C}-\mathrm{O}-\mathrm{C}$ stretching vibration of ether in $\beta-\mathrm{CD}$, demonstrating that FA binds chemically to poly- $\beta$-CD \\
$3,500-3,250$ & $\mathrm{O}-\mathrm{H}$ stretch \\
1282.6 & $\mathrm{O}-\mathrm{H}$ deflection \\
$2,960-2,850$ & the stretching vibration of $\mathrm{C}-\mathrm{H}$ \\
1,380 & the $\delta_{\mathrm{C}-\mathrm{H}}$ of $\mathrm{CH}_{3}$ \\
$1,200-1,050$ & the stretching vibration of $\mathrm{C}-\mathrm{O}$ \\
\hline
\end{tabular}

0.1

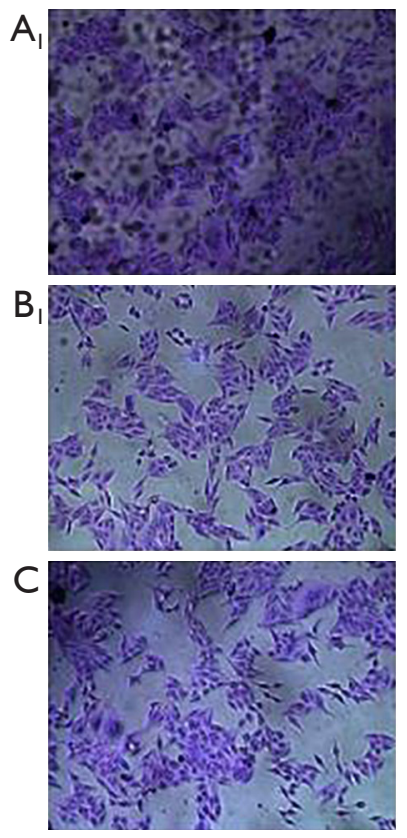

0.5
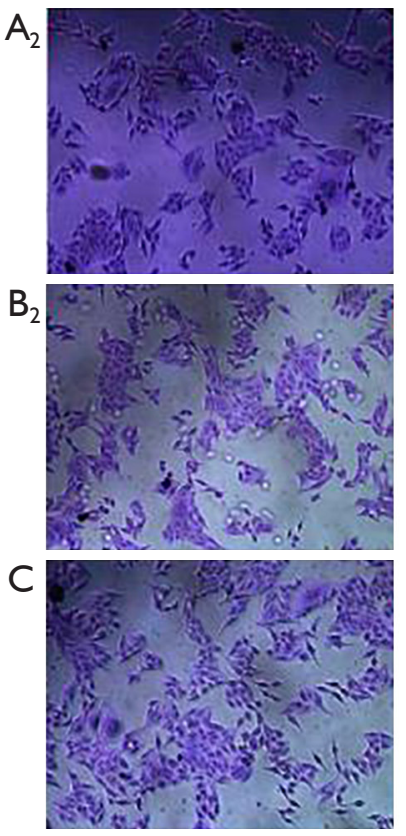

1
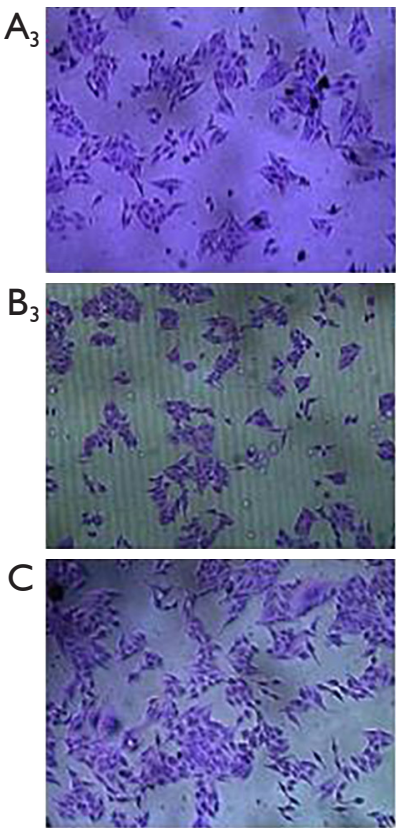

5
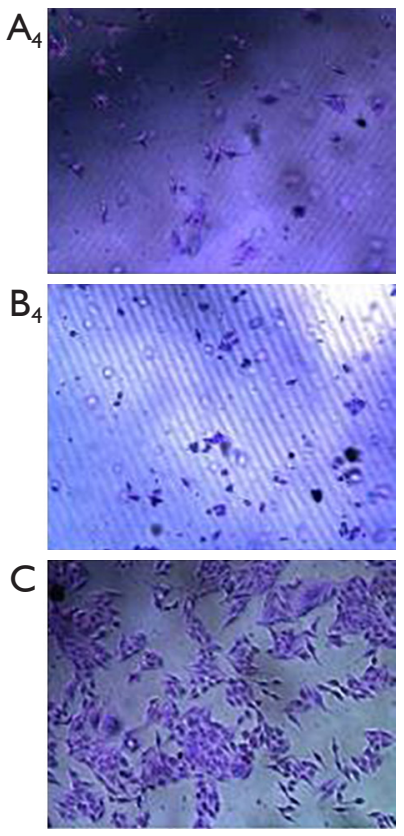

Figure 4 The cytopathic effect of poly- $\beta$-cyclodextrin, poly-CM- $\beta$-cyclodextrin and poly-GTAC- $\beta$-cyclodextrin on tumor cell HepG2. (A1, A2, A3 and A4) Represented the cytopathic effect of poly-CM- $\beta$-cyclodextrin. (B1, B2, B3 and B4) Represented the cytopathic effect of poly-GTAC- $\beta$-cyclodextrin. (C) was a blank control experiment. Tumor cell lines were seeded in 24 -well plates at a density of $5 \times 10^{4}$ cells for each well and incubated with poly- $\beta$-cyclodextrin, poly-CM- $\beta$-cyclodextrin or poly-GTAC- $\beta$-cyclodextrin at the indicated concentration $(\mathrm{mg} / \mathrm{mL})$. After $72 \mathrm{~h}$ incubation, cells in each well were exposed to $0.4 \mathrm{~mL} 2 \%$ crystal violet in $20 \%$ methanol for $30 \mathrm{~min}$ at room temperature and rinsed with distilled water in preparation for image analysis. magnification $100 \times$.

HepG2 cell viabilities were $~ 100 \%$ which indicated that no cytotoxicity of poly-GTAC- $\beta-C D$ and poly-CM- $\beta-C D$ at the concentration of $100-500 \mu \mathrm{g} / \mathrm{mL}$ was found. The results were consistent with the previous report, demonstrating that cyclodextrin exhibited no toxicity in vitro (23) and in vivo (24). However, poly-CM- $\beta-C D$ and poly-GTAC- $\beta-C D$ exhibited a slightly inhibitive effect on HepG2 cell lines at a concentration of $1,000 \mu \mathrm{g} / \mathrm{mL}$.

\section{Evaluation the potential of poly-GTAC- $\beta-C D-5-F U / p o l y-$ 5-FU inclusion compound for HepG2 cancer cells}

To determine the impact of negative and positive charges of inclusion compound on its antitumor efficient, the potential of poly- $\beta-C D-5-F U$, poly-GTAC- $\beta-C D-5-F U$, and poly5 -FU inclusion compound for HepG2 cancer cells were investigated by MTT assay. The phosphate-buffered saline 


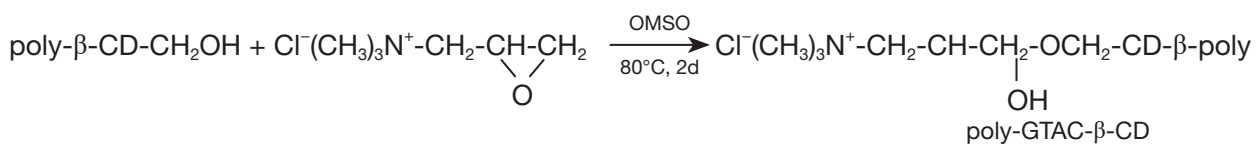

Figure 5 The preparation route and schematic diagram of poly-GTAC- $\beta-C D$.

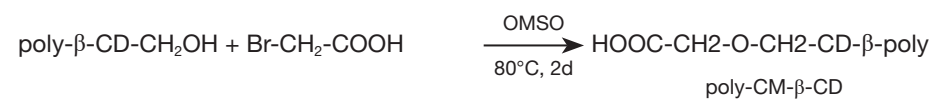

Figure 6 The preparation route and schematic diagram of poly-CM- $\beta-C D$.

was utilized as control. Figure 4 indicated that inclusion of model drug 5-FU into poly-GTAC- $\beta$-CD or poly-CM- $\beta$ $\mathrm{CD}$ had no impact on the potential of model drug $5-\mathrm{FU}$ for HepG2 cells and there was a significant difference in cytotoxicity among poly- $\beta-\mathrm{CD}-5-\mathrm{FU}$, poly-GTAC- $\beta-\mathrm{CD}-$ $5-\mathrm{FU}$ and poly-CM- $\beta-\mathrm{CD}$ inclusion compound.

\section{Discussion}

\section{Preparation Principle of poly-GTAM- $\beta-C D$}

The preparation route for poly-GTAC- $\beta-C D$ is shown in the schematic diagram of Figure 5 .

There was an ethylene oxide structural unit in GTMAC. Because of the large tension of the ternary ring, GTMAC was in high chemical activity, which can react with hydroxyl groups on poly- $\beta$-CD. There were primary hydroxyl and secondary hydroxyl groups in poly- $\beta$-CD but the chemical activity of primary hydroxyl was larger than that of secondary hydroxyl. Therefore, the groups of poly- $\beta$ CD which reacted with GTMAC were mainly primary hydroxyl. The ring-opening reaction between hydroxyl and ethylene oxide can be regarded as a special nucleophilic substitution reaction. GTMAC was soluble in $\mathrm{H}_{2} \mathrm{O}$ and DMSO. However, poly- $\beta-C D$ was poorly soluble in water and well soluble in DMSO. Both GTMAC and poly- $\beta$ $\mathrm{CD}$ were polar compounds and the polar aprotic solvent is favorable for nucleophilic substitution reaction. Therefore, DMSO was used as a solvent in this reaction.

\section{Preparation Principle of poly-CM- $\beta-C D$}

The preparation route for poly-CM- $\beta-\mathrm{CD}$ is shown in the schematic diagram of Figure 6. The reaction of hydroxyl with dibromoacetic acid was belonging to the nucleophilic substitution reaction. Bromoacetic acid was well soluble in $\mathrm{H}_{2} \mathrm{O}$ or DMSO. But poly- $\beta-\mathrm{CD}$ was insoluble in $\mathrm{H}_{2} \mathrm{O}$ instead. Furthermore, due to hydrogen bonding, water molecules can form a hydration shell around the hydroxyl group on poly- $\beta-C D$, blocking the substitution reaction of hydroxyl with bromoacetic acid. Because the polar characteristic of GTMAC and poly- $\beta-C D$ was observed, DMSO was utilized as a solvent in this reaction.

\section{The analysis by ${ }^{1} \mathrm{H} N M R$ and IR spectroscopy of poly-CM- $\beta-C D$ and poly-GTAC- $\beta-C D$}

For the introduction of the quaternary ammonium group into $\beta$-CD, 2,3-epoxypropyl trimethylammonium chloride (Mw $152 \mathrm{Da}$ ) was selected as a reactant which reacted with methylol groups in $\beta$-CD, providing a physiologically stable ether bond. There were hydroxyl groups and methylol groups in $\beta$-CDs. The nucleophilic ability of methylol was stronger than that of hydroxyl. Therefore, 3-epoxypropyltrimethylammonium chloride was selected to favor the linkage of the methylol, resulting in poly-GTAC$\beta-C D$. To introduce carboxymethyl into $\beta-C D$, bromoacetic acid (Mw $139 \mathrm{Da}$ ) was used as a reactant which reacted with methylol groups of $\beta$-CD, providing a physiologically stable ether bond. There were hydroxyl groups and methylol groups in $\beta$-CDs. The nucleophilic ability of methylol was stronger than that of hydroxyl. Therefore, bromoacetic acid was selected to favor the linkage of the methylol, resulting in poly-CM- $\beta-C D$. All the unwanted residual and free reactants were removed by dialysis in later step. The ${ }^{1} \mathrm{H}$ NMR spectrum of poly-GTAC- $\beta$-CD showed all the characterization peaks of 2,3-epoxypropyltrimethylammo nium chloride, and poly- $\beta-C D$, demonstrating that $2,3-e p$ oxypropyltrimethylammonium chloride bound chemically 


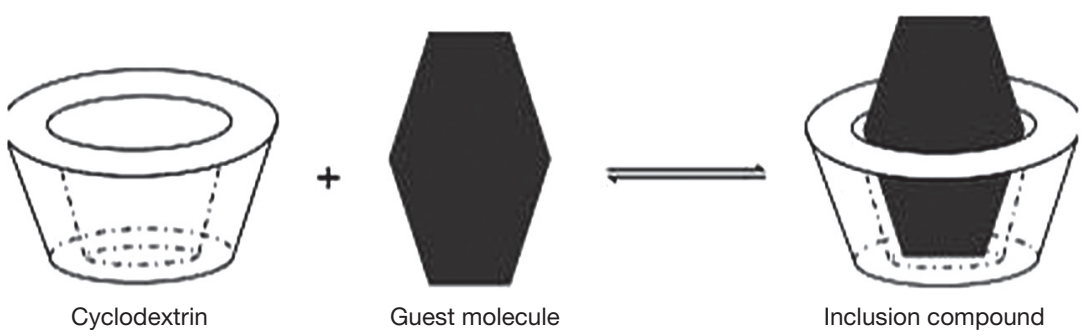

Figure 7 The schematic diagram for the formation of cyclodextrin-5-FU inclusion compound.

to poly- $\beta$-CD through an ether linkage. By the same token, the ${ }^{1} \mathrm{H}$ NMR spectrum of poly-CM- $\beta$-CD showed all the characterization peaks of $\mathrm{Br}-\mathrm{CH}_{2} \mathrm{COOH}$ and poly- $\beta-\mathrm{CD}$, suggesting that $\mathrm{Br}-\mathrm{CH}_{2} \mathrm{COOH}$ bound chemically to poly$\beta-C D$ through an ether linkage. The relevant signals of 2,3-epoxypropyltrimethylammonium chloride, and $\mathrm{Br}$ $\mathrm{CH}_{2} \mathrm{COOH}$ were too weak to be observed in ${ }^{1} \mathrm{H}$ NMR because there were overwhelming majority protons of poly$\beta$-CD than those of 2,3-epoxypropyltrimethylammonium chloride and $\mathrm{Br}-\mathrm{CH}_{2} \mathrm{COOH}$.

\section{Preparation principle of inclusion compound}

Figure 7 is a schematic diagram for the principle of inclusion compound. The lipophilic cavity of cyclodextrin molecules provided a microenvironment into which appropriately sized non-polar 5-FU can enter and form $\beta-\mathrm{CD}-5$-FU inclusion complexes (25). The hydrophobic drug 5 -FU could induce the $\beta$-CD conjugates to selfassemble and form nanoparticles (26). The main driving force for the formation of $\beta$-CD-5-FU inclusion complex was the release of enthalpy-rich water molecules from the hydrophobic cavity. Water molecules were displaced by the highly hydrophobic 5-FU molecules presenting in the solution to attain an apolar-apolar association and decrease of cyclodextrin ring strain, resulting in a stable lower energy state (27). Water was the most commonly used solvent in which complexation reactions were performed. The more soluble $\beta$-CD existed in the solvent, the more molecules became available for complexation. poly-CM- $\beta-C D$ and poly-GTAC- $\beta-C D$ are well soluble in water but $5-\mathrm{FU}$ is poorly soluble. However, poly-CM- $\beta-C D$, poly-GTAC- $\beta-C D$ and 5 -FU are all well soluble in DMSO. Therefore, DMSO was used as a solvent in this reaction to improve the formation of inclusion host-guest complexes.

\section{Cytotoxicity and uptake by tumor cells}

\section{In vitro cytotoxicity of poly-CM- $\beta-C D$ and poly-GTAC- $\beta-C D$}

With the increase of the concentration, the osmotic pressure of the solution would increase accordingly, which had a certain impact on cell growth. With the increase of the concentration of poly-CM- $\beta-C D$ or poly-GTAC- $\beta-C D$, HepG2 cell viabilities were seriously affected. In conclusion, the low concentration of poly-GTAC- $\beta-C D$ and poly-CM$\beta$-CD did not affect HepG2 cell growth, while the high concentration of poly-GTAC- $\beta-C D$ or poly-CM- $\beta-C D$ had an obvious effect on HepG2 cell growth. These results demonstrated that poly-GTAC- $\beta-C D$ and poly-CM- $\beta-C D$ can be used as drug carriers.

\section{Evaluation the potential of poly-GTAC- $\beta-C D-5-F U /$ poly-CM- $\beta-C D-5-F U$ inclusion compound for HepG2 cancer cells}

Significant difference in cytotoxicity among poly- $\beta-C D$ $5-\mathrm{FU}$, poly-GTAC- $\beta-\mathrm{CD}-5-\mathrm{FU}$ and poly-CM- $\beta-\mathrm{CD}$ inclusion compound was observed in Figure 8 . These results may be attributed to the involvement of charge in HepG2 cellular association and endocytosis of inclusion compounds. Zelepukin et al. reported that the effect of charge was a crucial factor when testing over eight NP formulations with different surface characteristics (28). The cell membrane is composed of the phospholipid bilayer with the negative charge on its surface. Thus, poly- $\beta-\mathrm{CD}-5-\mathrm{FU}$ can be swallowed by HepG2 cells through the weak electrostatic attraction hydrogen bond between hydroxyl and the negative charge on the cell membrane surface. The quaternary ammonium groups on poly-GTAC- $\beta$-CD-5-FU were positively charged (Zeta potential $+40.3 \mathrm{mV}$ ), which can form a strong electrostatic attraction with the negative charged on the HepG2 membrane. Consequently, poly-GTAC- $\beta$-CD-5-FU was more easily swallowed by HepG2 cells. However, the large steric hindrance 


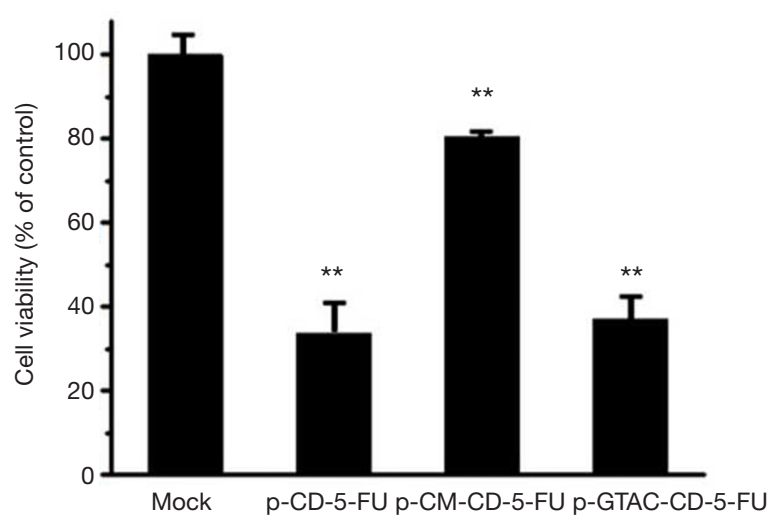

Figure 8 Cytotoxicity of poly- $\beta$-cyclodextrin loaded 5 -FU, polyGTAC- $\beta$-cyclodextrin loaded 5-FU, and poly-CM- $\beta$-cyclodextrin loaded 5-FU. HepG2 cells were incubated with poly- $\beta$-cyclodextrin loaded 5-FU, poly-GTAC- $\beta$-cyclodextrin loaded 5-FU and poly-CM$\beta$-cyclodextrin loaded 5 -FU at a 5 -FU concentration of $5 \mu \mathrm{g} / \mathrm{mL}$. After $24 \mathrm{~h}$ incubation, the survival ratios of HePG2 cells were determinate by MTT assay. Results were expressed as a relative percentage to untreated control HepG2 cells and represented the mean of four repetitive experiments. Significance is indicated by **, $\mathrm{P}<0.005$.

of the quaternary ammonium group blocked the endocytosis of poly-GTAC- $\beta-C D-5-F U$. Therefore, the killing effect of poly$\beta-\mathrm{CD}-5-\mathrm{FU}$ on HePG2 was similar to that of poly-GTAC$\beta-C D-5-F U$. For poly-CM- $\beta-C D-5-F U$, the dissociated carboxyl was negatively charged (Zeta potential $-56.3 \mathrm{mV}$ ), which can form electrostatic repulsion force with the negative charge on the HepG2 membrane surface. This made polyCM- $\beta-\mathrm{CD}-5-\mathrm{FU}$ difficult to approach cells and block the endocytosis of poly-CM- $\beta-C D$. Hence, poly-CM- $\beta-C D-5-$ FU had the worst killing effect on HePG2 cells. These results were consistent with the result reported by Frohlich (29). Charge is a key determinant of cellular localization, where highly positively charged NPs tend to show higher cellular uptake compared to negatively charged particles. It is worth pointing out that this high rate of accumulation also leads to increased non-specific binding to normal cells, and to cytotoxicity combined with a short half-life. In contrast, negatively charged NPs have very limited uptake in cells (29).

\section{Conclusions}

The current study demonstrated that the killing effect of poly- $\beta-\mathrm{CD}-5-\mathrm{FU}$ and poly-GTAC- $\beta-\mathrm{CD}-5-\mathrm{FU}$ on HePG2 cells was similar. By contrast, poly- $\beta-\mathrm{CD}-5-\mathrm{FU}$ revealed the worst killing effect on HePG2 cells. The feasibility of using poly- $\beta$-CD derivatives $t$ deliver 5 -FU was confirmed. $\beta-C D$ derivatives poly-GTAC- $\beta-C D$ and poly-CM- $\beta-C D$ had no cytotoxicity. The formation of inclusion complex between 5 -FU and poly-GTAC- $\beta-\mathrm{CD}$ or poly-CM- $\beta$ $\mathrm{CD}$ did not affect the antitumor activity of 5 -FU. Charge of nanoparticles played an important role in their cellular uptake. Poly- $\beta-C D$ derivatives have potential applications in sustained release and targeted drugs for tumor. Further studies in progress will study this novel poly- $\beta-C D$ derivatives drug delivery system in vivo.

\section{Acknowledgments}

Funding: Supported by grants from the Natural Science Foundation of Xiamen Medical College (K2017-04 and K2016-35) the open grants of engineering research center, ministry of education of molecular medicine. The funders had no role in the study design, data collection and analysis, decision to publish, or preparation of the manuscript.

\section{Footnote}

Data Sharing Statement: Available at http://dx.doi. org/10.21037/tcr-20-1118

Conflicts of Interest: All authors have completed the ICMJE uniform disclosure form (available at http://dx.doi. org/10.21037/tcr-20-1118). The authors have no conflicts of interest to declare.

Ethical Statement: The authors are accountable for all aspects of the work in ensuring that questions related to the accuracy or integrity of any part of the work are appropriately investigated and resolved.

Open Access Statement: This is an Open Access article distributed in accordance with the Creative Commons Attribution-NonCommercial-NoDerivs 4.0 International License (CC BY-NC-ND 4.0), which permits the noncommercial replication and distribution of the article with the strict proviso that no changes or edits are made and the original work is properly cited (including links to both the formal publication through the relevant DOI and the license). See: https://creativecommons.org/licenses/by-nc-nd/4.0/.

\section{References}

1. Abukhadra M, Allah A. Synthesis and characterization 
of kaolinite nanotubes (KNTs) as a novel carrier for 5 -fluorouracil of high encapsulation properties and controlled release. Inorg Chem Commun 2019;103:30-6.

2. Vatanparast $M$, Shariatinia $Z$. AlN and AlP doped graphene quantum dots as novel drug delivery systems for 5-fluorouracil drug: Theoretical studies. J Fluorine Chem 2018;211:81-93.

3. Praphakar RA, Jeyaraj M, Mehnath S, et al. A pH-sensitive guar gum-grafted-lysine- $\beta$-cyclodextrin drug carrier for the controlled release of 5 -flourouracil into cancer cells. J Mater Chem B 2018;6:1519-30.

4. Anirudhan TS, Divya P, Nima J. Synthesis and characterization of silane coated magnetic nanoparticles/ glycidylmethacrylate-grafted-maleated cyclodextrin composite hydrogel as a drug carrier for the controlled delivery of 5-fluorouracil. Mater Sci Eng C Mater Biol Appl 2015;55:471-81.

5. Chandran S, Natarajan S, Chandraseharan S, et al. Nano drug delivery strategy of 5 -fluorouracil for the treatment of colorectal cancer. J Cancer Res Pract 2017;4:45-8.

6. Dardir FM, Mohamed A, Abukhadra M, et al. Cosmetic and pharmaceutical qualifications of Egyptian bentonite and its suitability as drug carrier for Praziquantel drug. Eur J Pharm Sci 2018;115:320-9.

7. Rață DM, Cadinoiu A, Atanase L, et al. "In vitro" behaviour of aptamer-functionalized polymeric nanocapsules loaded with 5 -fluorouracil for targeted therapy. Mater Sci Eng C Mater Biol Appl 2019;103:109828.

8. Roy A, Maity P, Bose A, et al. $\beta$-Cyclodextrin based $\mathrm{pH}$ and thermo-responsive biopolymeric hydrogel as a dual drug carrier. Mater Chem Front 2019;3:385-93.

9. Hong $\mathrm{S}, \mathrm{Li} Z, \mathrm{Li} \mathrm{C}$, et al. $\beta$-Cyclodextrin grafted polypyrrole magnetic nanocomposites toward the targeted delivery and controlled release of doxorubicin. Appl Surf Sci 2018;427:1189-98.

10. Hariharan M, Sivaraj R, Ponsubha S, et al. 5 -Fluorouracil-loaded $\beta$-cyclodextrin-carrying polymeric poly(methylmethacrylate)-coated samarium ferrite nanoparticles and their anticancer activity. J Mater Sci 2019;54:4942-51.

11. Zhu G, Zhu G, Xiao Z. A review of the production of slow release flavor by formation inclusion complex with cyclodextrins and their derivatives. J Incl Phenom Macro 2019;95:17-33.

12. Nishijo J, Nagai M. Inclusion complex of 8 -anilinonaphthalene-1-sulfonate with $\beta$-cyclodextrin. J Pharm Sci 1991;80:58-62.
13. Tong WQ, Lach J, Chin T, et al. Structural effects on the binding of amine drugs with the diphenylmethyl functionality to cyclodextrins. I. A microcalorimetric study. Pharm Res 1991;8:951-7.

14. Tabushi I, Kiyosuke Y, Sugiomoto T, et al. Approach to the aspects of driving force of inclusion by alpha-cyclodextrin. J Am Chem Soc 1978;100:916-9.

15. Örstan A, Ross J. Investigation of the $\beta$-cyclodextrinIndole inclusion complex by absorption and fluorescence spectroscopies. J Phys Chem 1987;91:2739-45.

16. Wang J, Guo Z, Xiong J, et al. Facile synthesis of chitosangrafted $\beta$-cyclodextrin for stimuli-responsive drug delivery. Int J Biol Macromol 2019;125:941-7.

17. Sarfraz RM, Ahmad M, Mahmood A, et al. Development of $\beta$-cyclodextrin-based hydrogel microparticles for solubility enhancement of rosuvastatin: an in vitro and in vivo evaluation. Drug Des Devel Ther 2017;11:3083-96.

18. Ferraz CAA, de Oliveira Júnior RG, de Oliveira AP, et al. Complexation with beta-cyclodextrin enhances apoptosismediated cytotoxic effect of harman in chemoresistant BRAF-mutated melanoma cells. Eur J Pharm Sci 2020;150:105353.

19. Alizadeh N, Malakzadeh S. Antioxidant, antibacterial and anti-cancer activities of beta-and gamma-CDs/curcumin loaded in chitosan nanoparticles. Int J Biol Macromol 2020;147:778-91.

20. Li H, Gao Q, Wu G, et al. The preparation and characterization of 2-hydroxypropyl- $\beta$-cyclodextrin folate acid inclusion complexes. J Med Res 2013;42:98-101.

21. Li Y, Wang J, Wientjes M, et al. Delivery of Nanomedicines to extracellular and intravcellular compartments of a solid tumor. Adv Drug Deliv Rev 2012;64:29-39.

22. Taurin S, Nehoff H, Greish K. Anticancer nanomedicine and tumor vascular permeability; Where is the missing link? J Control Release 2012;164:265-75.

23. Carneiro SB, Costa Duarte F, Heimfarth L, et al. Cyclodextrin-drug inclusion complexes: In vivo and in vitro approaches. Int J Mol Sci 2019;20:642.

24. Hyun H, Lee S, Lim W, et al. Engineered betacyclodextrin-based carrier for targeted doxorubicin delivery in breast cancer therapy in vivo. J Ind Eng Chem 2019;70:141-51.

25. Loftsson T, Brewster M. Pharmaceutical applications of cyclodextrins. 1. Drug solubilization and stabilization. J Pharm Sci 1996;85:1017-25.

26. Zhang H, Cai Z, Sun Y, et al. Folate-conjugated $\beta$-cyclodextrin from click chemistry strategy and for tumor-targeted drug delivery. J Biomed Mater Res A 
2012;100:2441-9.

27. Szejtli J. Introduction and general overview of cyclodextrin chemistry. Chem Rev 1998;98:1743-54.

28. Zelepukin IV, Yaremenko AV, Shipunova VO, et al.

Nanoparticle-based drug delivery via RBC-hitchhiking

Cite this article as: $\mathrm{Li} \mathrm{H}, \mathrm{Zhu} \mathrm{S,} \mathrm{Xu} \mathrm{L,} \mathrm{Chen} \mathrm{Y}, \mathrm{Li} \mathrm{X}, \mathrm{Wu} W$. Novel poly- $\beta$-cyclodextrin derivatives as advanced carriers for 5 -fluorouracil for tumor: the impact of charge on antitumor efficiency. Transl Cancer Res 2020;9(8):4596-4606. doi: 10.21037/ tcr-20-1118 for the inhibition of lung metastases growth. Nanoscale 2019;11:1636-46.

29. Fröhlich $\mathrm{E}$. The role of surface charge in cellular uptake and cytotoxicity of medical nanoparticles. Int J Nanomedicine 2012;7:5577-91. 